\title{
Characteristics of carcasses and meat from feedlot lambs fed with sunflower cake
}

\section{Características da carcaça e da carne de cordeiros confinados alimentados com torta de girassol}

\author{
Euclides Reuter de Oliveira ${ }^{1}$; Flávio Pinto Monção ${ }^{2 *}$; \\ Andréa Maria de Araújo Gabriel ${ }^{1}$; Alexandre Rodrigo Mendes Fernandes ${ }^{1}$; \\ Felipe de Almeida Nascimento ${ }^{3}$; Felipe de Souza Abreu; \\ Leandro do Valle Mendes da Silva ${ }^{5}$; Loan Henrique Pereira da Silva ${ }^{5}$
}

\begin{abstract}
The aim of the experiment was to evaluate the characteristics of the carcasses and meat of feedlot lambs that received diets supplemented with sunflower cake; correlations among the variables were also performed. The experimental design was a randomized block design with four treatments (sunflower cake added at $0,10,20$, and $30 \%$ dry matter to the base diet) and seven replications per treatment. The diets were formulated with genotypes of Cynodon hay and corn- and soybean meal-based concentrate that were premixed at the ratio of 50:50 (hay:concentrate) and were fed to the lambs in two portions daily at 08:00 and 14:00. The feed conversion of the animals was adversely affected $(\mathrm{P}<0.05)$ by the increase in the feedlot period in the individual stalls. For each additional day of confinement, the feed conversion increased by $0.0096 \mathrm{~kg} \mathrm{DM} / \mathrm{kg}$ of weight gain. Based on the linear regression model for the average loin $\mathrm{pH}$, one hour after slaughter, the $\mathrm{pH}$ was reduced by 0.04 units. The marginal change in $\mathrm{pH}$ between the longest and the shortest times after slaughter was $14.11 \%$. The weights of the animals at slaughter were not significantly correlated with the carcass yields. Sunflower cake is a suitable dietary supplement for lambs in intensive production systems and can be a substitute for soybean meal at up to $20 \%$.
\end{abstract}

Key words: By-products, feed conversion, $\mathrm{pH}$, sheep, yield

\section{Resumo}

Objetivou-se por meio deste experimento avaliar o desempenho e características da carcaça e da carne de cordeiros confinados recebendo torta de girassol na dieta, bem como suas correlações. $\mathrm{O}$ delineamento empregado foi bloco ao acaso com quatro tratamentos $(0,10,20,30 \%$ de inclusão de

${ }^{1}$ Profs. Drs., Faculdade de Ciências Agrárias, Universidade Federal da Grande Dourados, UFGD, Dourados, MS, Brasil. E-mail: euclidesoliveira@ufgd.edu.br; andrea.gabriel@ufgd.edu.br; alexandrefernandes@ufgd.edu.br

2 Discente do Curso de Doutorado do Programa de Pós-Graduação em Zootecnia, Faculdade de Ciências Agrárias e Veterinária, Universidade Estadual Paulista "Júlio de Mesquita Filho", UNESP, Bolsista FAPESP, Jaboticabal, SP, Brasil. E-mail: moncaomoncao@yahoo.com.br

3 Discente do Curso de Mestrado do Programa de Pós-Graduação em Zootecnia, Faculdade de Ciências Agrárias e Veterinária, Universidade Estadual Paulista "Júlio de Mesquita Filho", UNESP, Jaboticabal, SP, Brasil. E-mail: phelipe_nascimento@ hotmail.com

${ }^{4}$ M.e em Zootecnia, Faculdade de Ciências Agrárias, UFGD, Dourados, MS, Brasil. E-mail: felipessabreu@yahoo.com.br

${ }^{5}$ Discentes de Graduação do Curso de Zootecnia, Faculdade de Ciências Agrárias, Universidade Federal da Grande Dourados, Dourados, MS, Brasil. E-mail: valle_leandro@hotmail.com; henriqueloan@hotmail.com

* Author for correspondence 
torta de girassol na ração base na matéria seca) com sete repetições. As rações foram formulados com fenos de genótipos de Cynodon e concentrado a base de Milho, farelo de soja e premix na relação de 50:50 (Feno: Concentrado),fornecidas em duas porções diária às 8:00 e 14:00 horas. O incremento no tempo de confinamento, afetou negativamente $(\mathrm{P}<0,05)$ a conversão alimentar dos animais. Verificou-se que para cada dia aumentado no confinamento, houve adição de $0,0096 \mathrm{~kg}$ de $\mathrm{MS} / \mathrm{kg}$ de peso ganho na conversão alimentar. Verificou-se que as médias do $\mathrm{pH}$ do lombo ajustaram-se ao modelo linear de regressão, sendo observado que à medida que aumentou uma hora após abate, houve redução de 0,04 unidades no $\mathrm{pH}$. A variação marginal do $\mathrm{pH}$ entre o maior e menor tempo após abate foi de $14,11 \%$. $\mathrm{O}$ peso dos animais ao abate não apresentou correlação significativa com os rendimentos na carcaça. A torta de girassol pode ser utilizada em suplementos para cordeiros em sistemas intensivos de produção, em substituição parcial ao farelo de soja em até $20 \%$.

Palavras-chave: Coprodutos, conversão alimentar, $\mathrm{pH}$, ovinos, rendimento

\section{Introduction}

The increase in demand for quality meat and the competitiveness with other markets require more efficient techniques in the current animal production systems in Brazil.

Among the animal production systems, the intensive production of lambs is a notable reflection of the increased market demand, particularly in the central region of Brazil. To supply the demand, feedlot strategies are used to finish the animals at an early stage and to obtain carcasses that are homogenous. However, animal feed is one of the factors that increases the cost of production, primarily in intensive or semi-intensive production systems (AZEVEDO et al., 2012). Thus, the alternative feeds supplied by the agro-industry such as cakes, sharps and other derivatives have received special attention, particularly when these alternative feeds are low in cost for a specific region (MONÇÃO et al., 2014).

Sunflower cake is a by-product of the processing of sunflower grain (Helianthus annuus L.), which is an annual dicot in the family Compositae that originated on the North American continent. Sunflower cake is used as an energy source for ruminants and is notable for its high lipid content (>35\%) (DOMINGUES et al., 2010; GOES et al., 2012). Additionally, sunflower cake is an alternative source of protein and energy for ruminants, with a crude protein $(\mathrm{CP})$ content of $23,50 \%$, an average total digestible nutrient (TDN) content of 79,70\% and a lipid content of $16,50 \%$ (DOMINGUES et al., 2010; GOES et al., 2012). However, the correlations between the qualitative characteristics of the meat and carcass with the diet of the animal in vivo as a decision-making tool have not been adequately investigated. Furthermore, when new ingredients are introduced in the diet, such as sunflower cake, the feedlot performance of the animal and the characteristics related to the carcass, which are essential in the consumer evaluation of meat quality, must be examined.

Therefore, the aims of this study were to determine 1) the optimum level of sunflower cake addition to the animal feed, with evaluations of feed conversion efficiency over time and 2) the correlations between slaughter weights and the characteristics of the carcasses and meat of feedlot lambs.

\section{Materials and Methods}

The experiment was conducted in accordance with the rules approved by the ethics and biosafety committee of the institution, the Universidade Federal da Grande Dourados, for the use of animals in research under protocol number 223/07.

The experiment was conducted in the Zootecnia sector of the Agricultural Sciences Faculty, Federal University of Grande Dourados-FCA/UFGD, located in the city of Dourados-MS. 
Twenty-eight male Suffolk crossbred sheep that were 4 months of age and an average weight of $21 \pm 0.38 \mathrm{~kg}$ were used. The animals were distributed into weight categories (low, medium and high) and four treatment groups (control (0), 10,20 , and $30 \%$ additions of sunflower cake to the base diet) with seven replications in a randomized block design. The animals were identified with numbered earrings and were dewormed with $1 \%$ ivermectin by mouth to control endo- and ectoparasites.

The animals were maintained for an average period of $120 \mathrm{~d}$ under confined conditions, which was preceded by 14 days for adaptation to the management and diets. The sheep were randomly assigned to individual $1.5 \mathrm{~m}^{2}$ stalls in 2 covered sheds with concrete floors that were lined with shavings, and the stalls had curtains for temperature control, a drinker and a mobile trough.

The diets were formed from the control treatment in which corn and soybean meal were the sources of protein and energy. In the other treatments, the sunflower cake was added at $10 \%, 20 \%$ and $30 \%$ and replaced corn and soybean meal in the base diet; the four treatments were isoproteic, averaging 17,94\% CP (DM).

The diets, based on volume, were composed of Tifton 85, Tifton 68 and Jiggs (Cynodon spp.) hay, a concentrate composed of ground corn, minerals, and soybean meal and sunflower cake (control, 10, 20, and $30 \%$ addition of sunflower cake to the base diet) and were formulated according to the NRC (2007) to meet the nutritional requirements of animals to gain $200 \mathrm{~g} /$ day (Table 1).

Table 1. Composition of experimental diets according to the sunflower cake inclusion levels in the concentrate

\begin{tabular}{lcccc}
\hline \multirow{2}{*}{ Ingredients } & \multicolumn{4}{c}{ Level of inclusion of sunflower cake } \\
\cline { 2 - 4 } & $0 \%$ & \multicolumn{4}{c}{$10 \%$} & $20 \%$ & $30 \%$ \\
\hline Foods & 50.00 & 50.00 & 50.00 & 50.00 \\
\hline Hay Cynodon & 0.00 & 10.00 & 20.00 & 30.00 \\
Sunflower cake & 29.65 & 22.71 & 15.77 & 8.83 \\
Corn Grain Ground & 19.41 & 16.37 & 13.33 & 10.29 \\
Soy bean meal & 0.20 & 0.20 & 0.20 & 0.20 \\
Mineral premix & 0.73 & 0.71 & 0.69 & 0.68 \\
Calcareous & & Bromatological composition $(\%$ DM) & \\
\hline Components & 87.24 & 87.26 & 88.37 & 88.77 \\
Dry Matter & 17.98 & 18.15 & 17.97 & 17.66 \\
Crude Protein & 1.27 & 3.43 & 5.63 & 7.18 \\
Ether extract & 60.22 & 61.96 & 62.54 & 60.33 \\
NDF & 30.51 & 29.83 & 29.51 & 26.80 \\
ADF & 56.60 & 55.60 & 55.30 & 56.54 \\
$*$ TDN & 6.63 & 7.01 & 6.50 & 6.72 \\
Mineral matter & & & & \\
\hline
\end{tabular}

* Estimate as Cappelle et al. (2001) $(\mathrm{TDN}=91,0246$ - 0,571588*NDF); Mineral mixture for ovines $(\mathrm{P}=72 \mathrm{~g} / \mathrm{kg}$; Ca = $111 \mathrm{~g} / \mathrm{kg}$; $\mathrm{Na}=174 \mathrm{~g} / \mathrm{kg} ; \mathrm{Mg}=9 \mathrm{~g} / \mathrm{kg} ; \mathrm{S}=12 \mathrm{mg} / \mathrm{kg} ; \mathrm{Zn}=7.200 \mathrm{mg} / \mathrm{kg} ; \mathrm{Cu}=600 \mathrm{mg} ; \mathrm{Mn}=1.550 \mathrm{mg} / \mathrm{kg} ; \mathrm{Fe}=4,42 \mathrm{mg} / \mathrm{kg} ; \mathrm{Co}=50 \mathrm{mg} / \mathrm{kg} ;$ $\mathrm{I}=75 \mathrm{mg} / \mathrm{kg} ; \mathrm{Se}=13,50 \mathrm{mg} / \mathrm{kg}$; fluorine $(\max )=720 \mathrm{mg} / \mathrm{kg})$.

The sunflower cake was obtained from the solvents, and all plant material was processed in a mechanical pressing of grain without using single period on a single machine (MUE-100 for 
cold extraction).

The experimental diet was based on a pre-trial phase in which the amount provided was based on individual consumption. The forage:concentrate ratio of 50:50 was determined on the basis of dry matter (DM). The daily consumption of the diets was determined based on $5 \%$ to $10 \%$ of the food remaining. The feed was provided twice daily at 08:00 and 14:00.

All the food provided, including the remains, was weighed to calculate the feed conversion. The weights of the animals were measured at the beginning of the experiment and at 14-d intervals, after a period of fluid and solid fasting for $16 \mathrm{~h}$, using a mechanical scale with a capacity of $100 \mathrm{~kg}$.

At the end of the experiment, the animals were slaughtered in the experimental slaughterhouse of "Fazenda experimental da UFGD" following the stunning procedures for electronarcosis and the subsequent bleeding by sectioning of the jugular veins and carotid arteries (CEZAR; SOUZA, 2007). The hot carcass weights were obtained at slaughter, and the carcass yields were obtained from the ratios between hot carcass weights $(\mathrm{HCW})$ and slaughter weights (SW) of the animals. The carcasses were transported to a refrigeration chamber for $24 \mathrm{~h}$ at $3^{\circ} \mathrm{C}$. After this period, the carcasses were weighed to obtain the cold carcass weights $(\mathrm{CCW})$, and the cold carcass yields (CCY) were calculated from the ratios between the weights of chilled carcasses (PCR) and the slaughter weights (SW). The $\mathrm{pH}$ was measured (potential of hydrogen) with a digital $\mathrm{pH}$ meter (model IPHPJ, Jonhis mark) by introducing the electrode directly into the Triceps brachii palette muscle, the Semimembranosus leg muscle, and the Longissimus lumborum loin muscle, with three measurements taken in each location on the right side of carcass.

In a transverse cut between the 12th and 13th ribs, a caliper was used to measure the thickness of the exposed fat in the third quarter of the Longissimus dorsi muscle from the spine. The area of the loin eye was measured by tracing the perimeter of the muscle on vegetable parchment, which was followed by planimetry using AutoCAD R14 software, as described by Oliveira et al. (2010).

Three samples approximately $2.5 \mathrm{~cm}$ in thickness of the Longissimus dorsi muscle were removed from the 12th rib and immediately sent to the laboratory for analysis of the meat color. The meat color determinations were performed as described by Houben et al. (2000), using a colorimeter (Konica Minolta $($ )). Thirty minutes before the evaluations, a cross-section of the muscle exposed the myoglobin to oxygen, as described by Fernandes et al. (2011).

In the sensorial analysis, the meat samples received an addition of $1,5 \%$ salt based on the weights and were roasted in a preheated oven at $175^{\circ} \mathrm{C}$ until the internal temperature of the meat reached $75^{\circ} \mathrm{C}$. The tasting was conducted by 20 trained tasters, with a nine point hedonic scale that considered the texture attribute (i.e., the perception of strength required to shear the sample when biting).

The levels of sunflower cake addition to the diets were evaluated with orthogonal contrasts for which the best fit was obtained by testing linear, quadratic and cubic models with the SAS Statistical Software package (2008).

Correlations were performed among the characteristics of performance (slaughter weights and yields), the carcass (internal carcass length, fat thickness, loin eye area and marbling) and the meat quality (texture and color) using the CORR procedure in the SAS statistical software package (SAS, 2008).

\section{Results and Discussion}

The inclusion of $30 \%$ of sunflower cake in the diet of lambs negatively affected the performance of animals (Table 2). There was a significant linear decrease of $0.15 ; 0.11 ; 0.12$ and $0.002 \%$ in slaughter weight $(\mathrm{SW})$, hot carcass weight $(\mathrm{HCW})$, cold 
carcass weight $(\mathrm{CCW})$ and compactness index $(\mathrm{CI})$, respectively when it increased $1 \%$ in the inclusion of the sunflower cake in the diet (Table 2).

Consequently, the hot carcass (HCY) and cold carcass yields (CCY) decreased with the additions of sunflower cake. Based on the linear regression model, the HCY and the CCY decreased 0.13\% and $0.16 \%$, respectively, for each percentage unit of sunflower cake added to the diet. The differences in the HCY and the CCY between the groups that received the highest level of addition and the controls without the addition of sunflower cake were $7.36 \%$ and $10.05 \%$, respectively. Most likely, these reductions in yield occurred because of the variability in the absolute values of the SW, $\mathrm{HCW}$ and $\mathrm{CCW}$ with the additions of sunflower cake to the diet.

Table 2. Final live body weight, cold carcass weight, gross income and net revenue of feedlot lambs fed diets with different levels of sunflower cake

\begin{tabular}{lccccc}
\hline \multirow{2}{*}{ Variable } & \multicolumn{5}{c}{ Inclusion Level(\%) } \\
\cline { 2 - 5 } & 0 & 10 & 20 & 30 & $\mathrm{CV}$ \\
\hline Weight at slaughter( $(\mathrm{kg})^{1}$ & 37.04 & 34.16 & 35.79 & 31.47 & 7.24 \\
Hot carcass weight $(\mathrm{kg})^{2}$ & 16.95 & 15.49 & 15.00 & 13.27 & 6.91 \\
Cold carcass weight $(\mathrm{kg})^{3}$ & 16.21 & 14.69 & 14.26 & 12.34 & 6.48 \\
Hot carcass yield( $(\%)^{4}$ & 45.74 & 45.38 & 41.91 & 42.38 & 5.93 \\
Cold carcass yield $(\%)^{5}$ & 43.74 & 43.08 & 39.86 & 39.34 & 4.14 \\
$\hat{\mathrm{Y}}^{1}=36,87-0,15^{* *} \mathrm{X}, \mathrm{R}^{2}=0,65 ; \hat{\mathrm{Y}}^{2}=16,90-0,11^{* *} \mathrm{X}, \mathrm{R}^{2}=0,96 ; \hat{\mathrm{Y}}^{3}=16,17-0,12^{* *} \mathrm{X}, \mathrm{R}^{2}=0,95 ; \hat{\mathrm{Y}}^{4}=45,88-0,13^{* *} \mathrm{X}, \mathrm{R}^{2}=0,77 ;$ \\
$\hat{\mathrm{Y}}^{5}=43,97-0,16^{*} \mathrm{X}, \mathrm{R}^{2}=0,90 . \mathrm{CV}$ - Coefficient of Variation.
\end{tabular}

For the feed conversion (FC), a significant difference was detected for the feedlot period of the lambs that were affected by the levels of sunflower cake addition (Table 3). However, the interaction between inclusion level and feedlot period was not significant $(\mathrm{P}>0.05)$.

Table3. Effect of sunflower cake and feedlot period on feed conversion (FC) of lambs.

\begin{tabular}{cccccc}
\hline \multirow{2}{*}{$\begin{array}{c}\text { Inclusion Levels } \\
(\%)\end{array}$} & 30 & 60 & 90 & \multirow{2}{*}{ Averages } \\
\cline { 2 - 4 } & \multicolumn{5}{c}{ Time (Days) } \\
\hline & 4.56 & 5.07 & 5.26 & 5.34 & 5.05 \\
10 & 4.79 & 5.55 & 5.45 & 5.37 & 5.29 \\
20 & 4.84 & 5.99 & 6.23 & 5.73 & 5.70 \\
30 & 6.26 & 7.04 & 7.35 & 7.26 & 6.98 \\
\hline Averages & 5.11 & 5.91 & 5.92 & 6.07 & \\
\hline CV(\%) & \multicolumn{5}{c}{21.55} \\
\hline MSE & \multicolumn{5}{c}{0.2346} \\
\hline
\end{tabular}

CV- Coefficient of Variation; MSE- Mean Standard Error.

For each $1 \%$ increase in the level of sunflower of $0.062 \mathrm{~kg}$ of DM/ $\mathrm{kg}$ of weight gain (Figure 1). cake addition, a linear increase occurred in the FC The marginal variation was $38.21 \%$ between the 
control group (without sunflower cake) and the group that received $30 \%$ of sunflower cake. These results were explained by the high content of ether extract (Table 1) in the diet with the $30 \%$ addition of sunflower cake, which might have limited the nutrient intake and negatively affected the weight gain and the FC.

Diets with a high content of ether extract (above 5\%) lead to an increase in consumption (PALMQUIST; MATTOS, 2006) and the consequent activation of ruminal receptors, which enable the satiety center, controlled by the hypothalamus, to inhibit the intake of dry matter. However, the amount of ingested amino acids is not sufficient to satisfy the demand of the ruminal microflora, limiting microbial protein synthesis by the ruminal bacteria. Thus, the efficiency of nutrient use is reduced in these diets and results in lower performance, as noted in the FC results for the diet with 30\% sunflower cake. Another important factor that might explain the high FC in the diet with $30 \%$ sunflower cake was that the high content of ether extract $(7.18 \%$, unsaturated fatty acids; Table 1$)$ might have intoxicated the ruminal microorganisms in addition to forming a skin over the feed particles and reducing microbial adhesion and rumen fiber degradation (KOZLOWSKY, 2011). Therefore, animal performance was affected by the reduced rate of food passage from the rumen to the small intestine, which reduced nutrient availability for digestion and absorption.

Figure 1. Sunflower cake effect in the diet of lambs crossbred Suffolk on feed conversion.

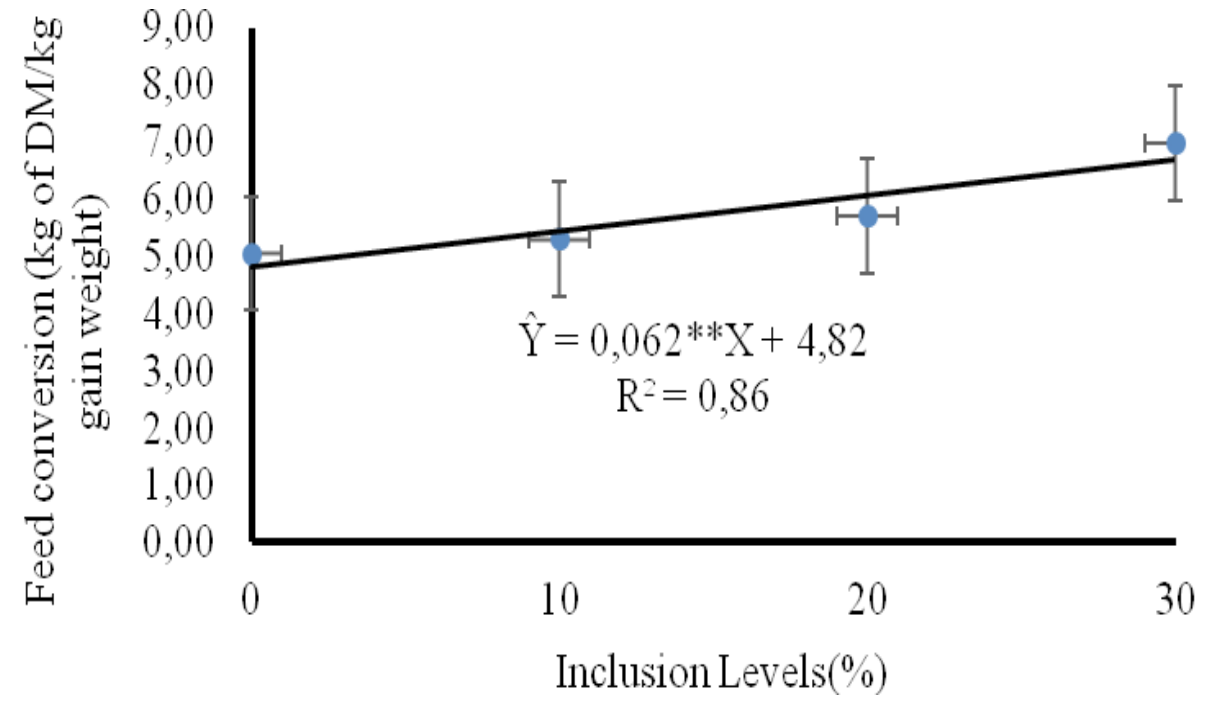

Based on the regression, an increase in the length of the feedlot period also negatively affected the FC of the animals, and for each additional day in the feedlot there was an additional $0.0096 \mathrm{~kg}$ of DM/ $\mathrm{kg}$ of weight gain (Figure 2) in the FC. 
Figure 2. Feed conversion (FC) of sulfolk crossbred lambs fed with diets containing sunflower cake in feedlot.

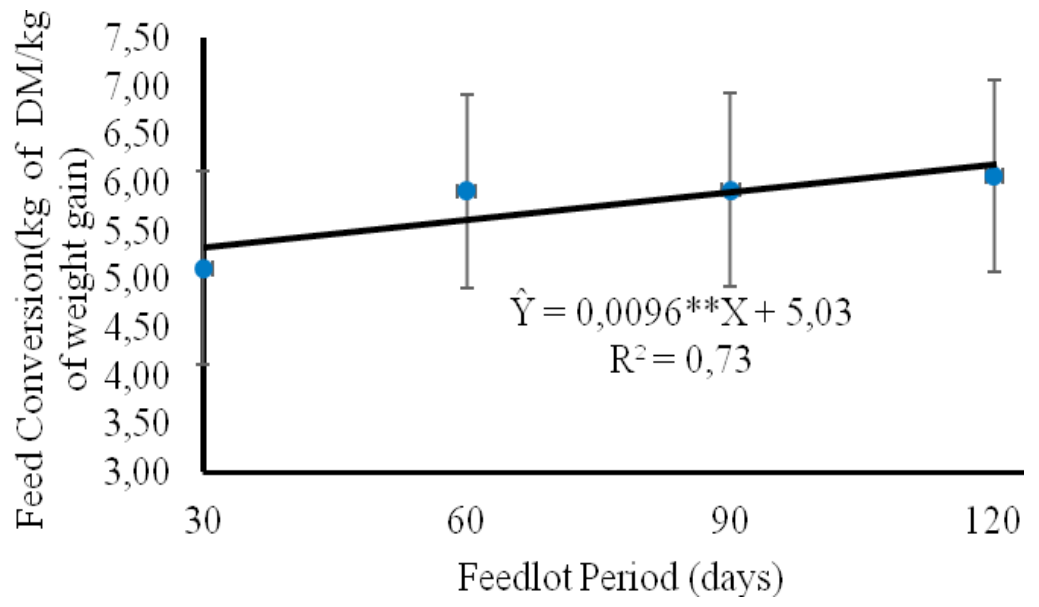

The increase in the FC of animals with more time in confinement might be related to the change in the growth curve of the animal because the increased deposition in muscles reduced the time required for the animal to reach early physiological maturity. From this stage of early maturity, the animal deposited more fat in the carcass because of the increase in the intake of nutrients and the reduction in weight gain, as shown in this research. The marginal variation in the $\mathrm{FC}$ between the longest and shortest feedlot periods was $15.81 \%$. According to Moreno et al. (2010), one of the strategies to minimize the FC in feedlots is to wean the lambs later when they are heavier, which is reflected in a shorter feedlot period and an improved FC.

For the parameters evaluated for the carcasses, such as the $\mathrm{pH}$, no significant differences among the levels of sunflower cake addition or for the interaction $(\mathrm{P}>0.05)$ between the sunflower cake levels and the time after slaughter were detected. However, significant differences in the $\mathrm{pH}$ were observed among measurement times in the carcass after slaughter (Table 4).

Table 4. Sunflower cake effect and the time after slaughter over the $\mathrm{pH}$ of loin lambs in feedlot.

\begin{tabular}{|c|c|c|c|c|c|c|}
\hline \multirow{2}{*}{ Inclusion Levels (\%) } & \multicolumn{5}{|c|}{ Period (hours) } & \multirow{2}{*}{ Average } \\
\hline & 0 & 6 & 12 & 18 & 24 & \\
\hline \multicolumn{7}{|c|}{ pH of Loin } \\
\hline 0 & 6.54 & 6.27 & 5.85 & 5.74 & 5.68 & 6.02 \\
\hline 10 & 6.60 & 6.32 & 5.95 & 5.77 & 5.66 & 6.06 \\
\hline 20 & 6.65 & 6.37 & 5.92 & 5.70 & 5.64 & 6.05 \\
\hline 30 & 6.58 & 6.21 & 5.76 & 5.72 & 5.67 & 5.99 \\
\hline Average & 6.59 & 6.29 & 5.87 & 5.73 & 5.66 & \\
\hline $\mathrm{CV}(\%)$ & \multicolumn{6}{|c|}{3.35} \\
\hline MSE & \multicolumn{6}{|c|}{0.0763} \\
\hline
\end{tabular}

CV- Coefficient of Variation; MSE- Mean Standard Error.

Figure 3 shows that as the time after slaughter $12 \mathrm{~h}$, with wide variations among the averages up increased the $\mathrm{pH}$ values were reduced linearly up to to $24 \mathrm{~h}$; thereafter, the variability of the $\mathrm{pH}$ values 
was reduced, and the $\mathrm{pH}$ stabilized at approximately 5.7. Thus, based on the best fit to a linear regression model, within one hour after slaughter, the $\mathrm{pH}$ decreased by 0.04 units. The marginal $\mathrm{pH}$ variation between the longest and the shortest times after slaughter was $14.11 \%$.

Pinheiro et al. (2009) evaluated the $\mathrm{pH}$ of the loin muscles (Longissimus lumborum) of lambs of the variety Ile de France vs. Ideal and reported values of 6.53 and $5.5345 \mathrm{~min}$ and $24 \mathrm{~h}$ after slaughter, respectively, which corroborates the results with this research. The reduction in the $\mathrm{pH}$ of the carcasses possibly occurred in response to the reduction of glycogen and led to an increase in lactic acid fermentation by muscle cells to survive. Thus, with the accumulation of lactic acid in the carcasses, the gradual reduction in $\mathrm{pH}$ occurred, as observed in this research.

The associated reduction in the $\mathrm{pH}$ and in the carcass temperature is critically important in the storage process and in the shelf life of the meat cuts. In this research, for the $\mathrm{pH}$ values in the palette of the lambs, no significant interaction between the cake levels and time after slaughter was detected (Table $5)$. However, there was an effect $(\mathrm{P}<0.05)$ from sunflower cake levels and the time after slaughter.

Figure 3. Effect of the period after slaughter on pH Carcass (Longissimus lumborum) of Sulfolk crossbred lambs finished in feedlot.

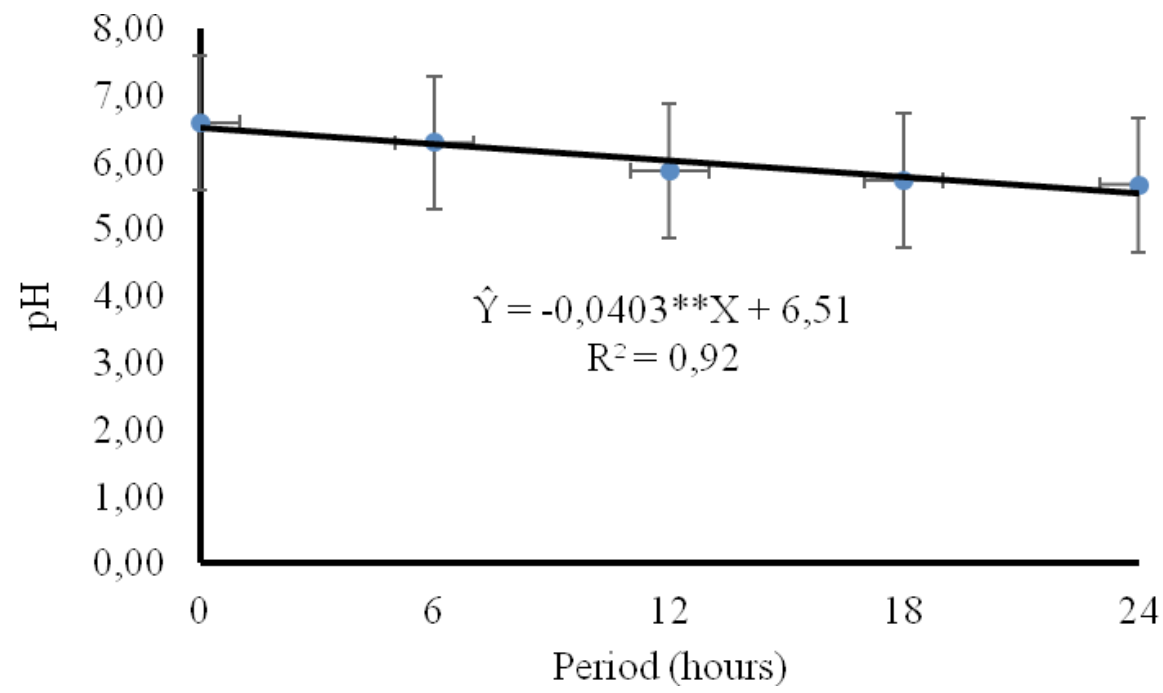

Table 5. Sunflower cake effect and the period after slaughter over the $\mathrm{pH}$ of the lambs palette in feedlot.

\begin{tabular}{|c|c|c|c|c|c|c|}
\hline \multirow{2}{*}{ Inclusion Levels (\%) } & \multicolumn{5}{|c|}{ Period (hours) } & \multirow{2}{*}{ Average } \\
\hline & 0 & 6 & 12 & 18 & 24 & \\
\hline & \multicolumn{5}{|c|}{ pH of Palette } & \\
\hline 0 & 6.62 & 6.17 & 6.01 & 5.93 & 5.76 & 6.10 \\
\hline 10 & 6.67 & 6.38 & 6.18 & 6.04 & 5.92 & 6.24 \\
\hline 20 & 6.55 & 6.14 & 5.95 & 5.76 & 5.71 & 6.02 \\
\hline 30 & 6.71 & 6.35 & 6.12 & 6.03 & 5.95 & 6.23 \\
\hline Average & 6.64 & 6.26 & 6.07 & 5.94 & 5.83 & \\
\hline $\mathrm{CV}(\%)$ & \multicolumn{6}{|c|}{3,00} \\
\hline MSE & \multicolumn{6}{|c|}{0.0311} \\
\hline
\end{tabular}

CV- Coefficient of Variation; MSE- Mean Standard Error. 
Although the increase in the $\mathrm{pH}$ of the palette was small, the increased levels of sunflower cake addition increased the $\mathrm{pH}$ values 0.0018 units for each $1 \%$ addition of the sunflower cake (Figure 4 ).

Pinheiro et al. (2009) reports $\mathrm{pH}$ values of 6.00 for the palettes of lambs, which approximated the values observed in this research. In the period after slaughter, the averages were fit to a linear regression model, as shown in Figure 5.

For each additional hour after slaughter, the $\mathrm{pH}$ decreased 0.03 units, indicating that the reduction was gradual, which is notable because of the undesirable aspects such as protein denaturation that occur when the $\mathrm{pH}$ is reduced abruptly and the temperature is elevated. Fernandes et al. (2011) report that the speed in the reduction of the $\mathrm{pH}$ and the final $\mathrm{pH}$ affect the water retention capacity, which is a qualitative characteristic of great importance because it affects the appearance, the behavior of the meat during cooking, and the juiciness during chewing. According to Lawrie (2005), the water is maintained by capillarity and is associated with proteinaceous filaments. Thus, the normal glycolysis postmortem occurs until a final $\mathrm{pH}$ of approximately 5.5 , the isoelectric point of the major muscle proteins responsible for the water retention capacity, is reached.

Figure 4. Sunflower cake effects on the diet for lambs over the $\mathrm{pH}$ of the palette.

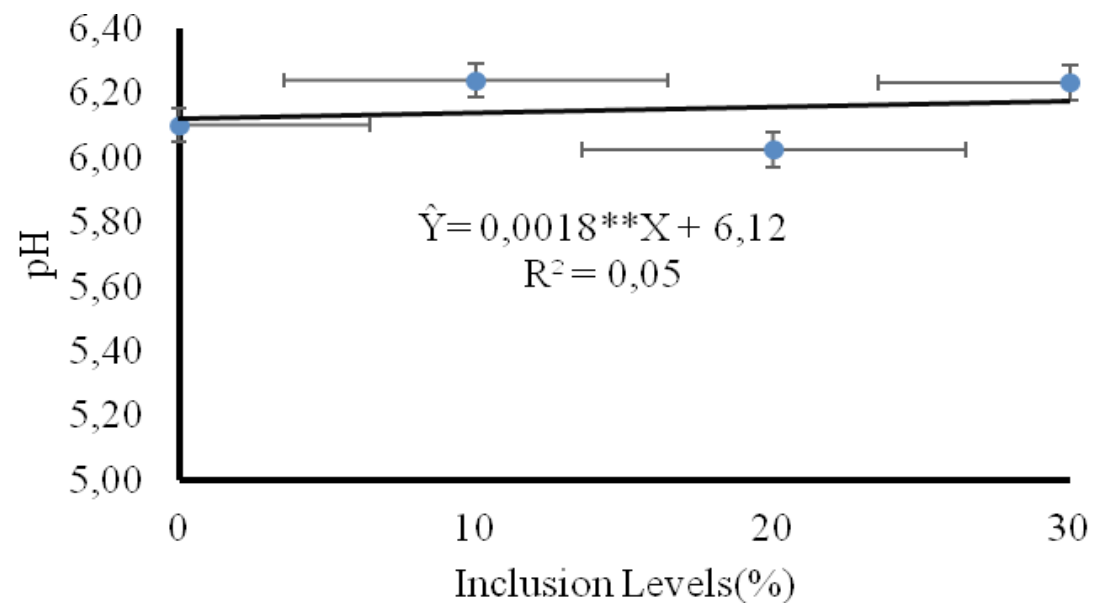

Figure 5. Effect of the period after slaughter, over the $\mathrm{pH}$ of palette of Sulfolk crossbred lambs finished in feedlot.

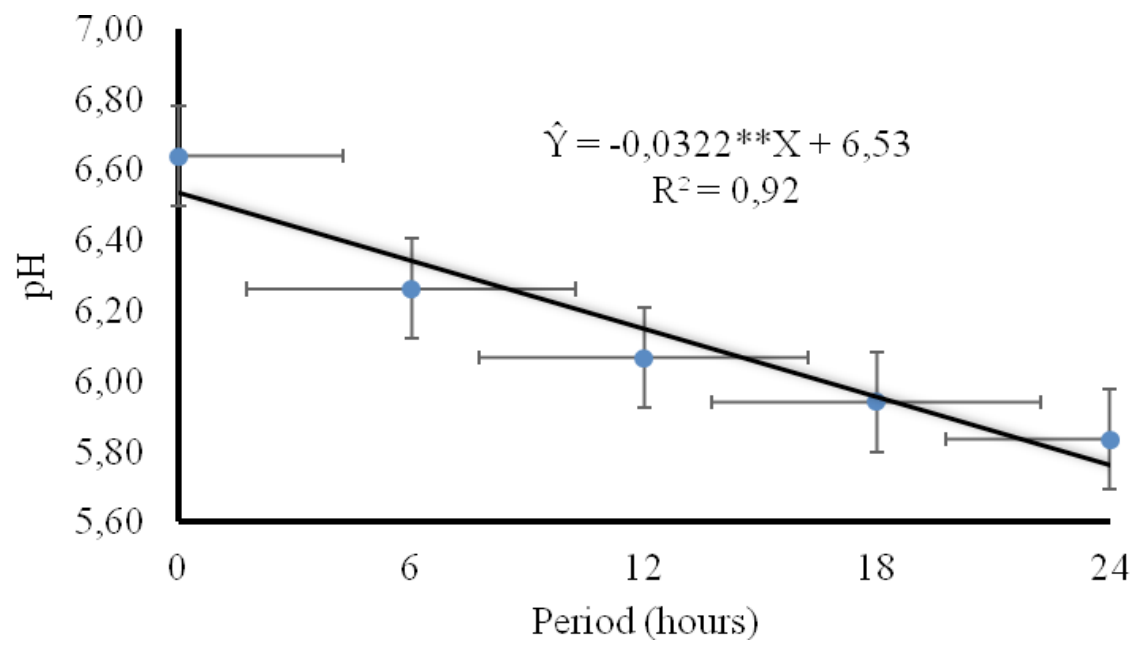


The average $\mathrm{pH}$ values for the loin, palette and leg muscles (Table 6) $24 \mathrm{~h}$ after slaughter were approximately 5.66, 5.83 and 5.63, respectively. These values are normal for sheep meat, according to the work of Pinheiro et al. (2009) who report average values of 5.53, 5.50 and 5.55, respectively, for different categories of animals. According to Cezar and Souza (2007), final pH values lower than 5,4 result in PSE meat (pale, soft, and exudative), which is rarely observed, particularly in ovines. The PSE condition decreases the water retention capacity, and therefore, the meat is flaccid and pale, negatively affecting consumer acceptance. However, at values above 6.0, the meat darkens (DFD-dark, firm, and dry) and water retention capacity and enzyme activity increase in the meat, reducing the shelf life (LAWRIE, 2005).

A significant interaction between the level of sunflower cake and the time after slaughter was not observed for the $\mathrm{pH}$ of the leg. However, there were differences $(\mathrm{P}<0.05)$ among the average $\mathrm{pH}$ values of the leg in response to the level of sunflower cake and the time after slaughter.

Table 6. The effect of sunflower cake and time after slaughter over the $\mathrm{pH}$ of the lambs leg in feedlot.

\begin{tabular}{|c|c|c|c|c|c|c|}
\hline \multirow{2}{*}{ Inclusion Levels (\%) } & \multicolumn{5}{|c|}{ Time after slaughter (hours) } & \multirow{2}{*}{ Average } \\
\hline & 0 & 6 & 12 & 18 & 24 & \\
\hline & \multicolumn{5}{|c|}{$\operatorname{Leg} p H$} & \\
\hline 0 & 6.67 & 6.21 & 5.83 & 5.68 & 5.64 & 6.01 \\
\hline 10 & 6.83 & 6.44 & 6.22 & 5.81 & 5.64 & 6.19 \\
\hline 20 & 6.64 & 6.07 & 5.91 & 5.83 & 5.70 & 6.03 \\
\hline 30 & 6.56 & 6.01 & 5.71 & 5.57 & 5.53 & 5.88 \\
\hline Average & 6.68 & 6.18 & 5.92 & 5.72 & 5.63 & \\
\hline $\mathrm{CV}(\%)$ & \multicolumn{6}{|c|}{3.85} \\
\hline MSE & \multicolumn{6}{|c|}{0.0392} \\
\hline
\end{tabular}

CV- Coefficient of Variation; MSE- Mean Standard Error.

The averages were fit to a quadratic regression the cake level that maximized the $\mathrm{pH}$ value was model with the increments of sunflower cake, and $12.31 \%$ (Figure 6).

Figure 6. Effects of sunflower cake inclusion in the diet to lambs over the $\mathrm{pH}$ of the leg.

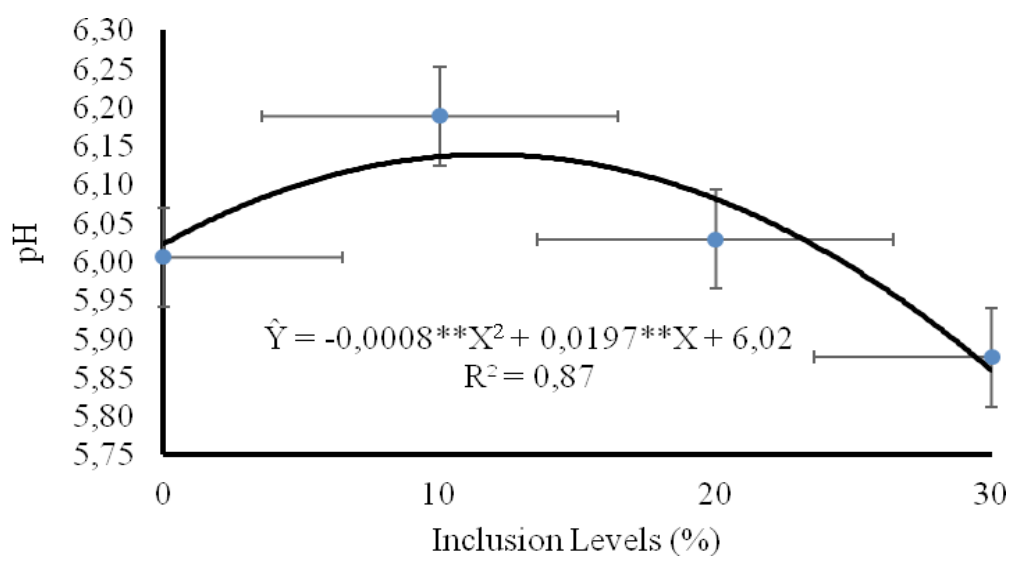


The average $\mathrm{pH}$ values of the leg over time were the period with the lowest $\mathrm{pH}$ value was $24.70 \mathrm{~h}$ also fit to a quadratic regression model from which after slaughter (Figure 7).

Figure 7. Time effect after slaughter, over the leg $\mathrm{pH}$ of Sulfolk crossbred lambs finished in feedlot.

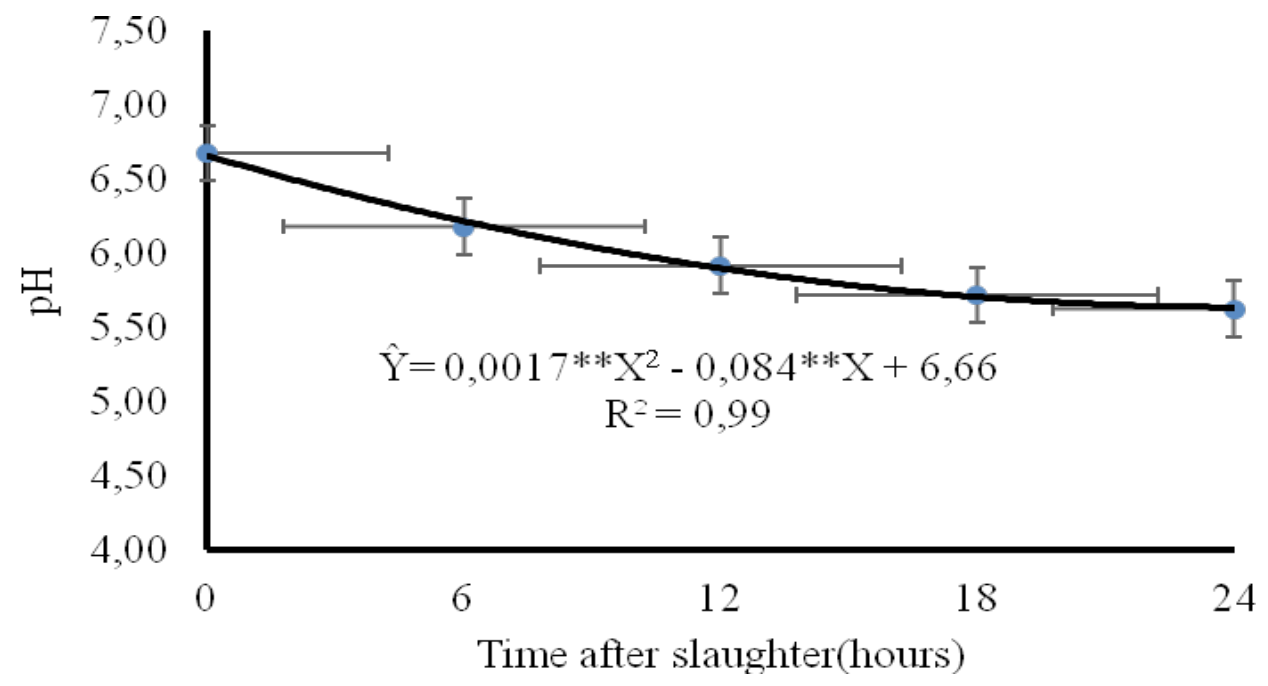

Based on the correlation analyses, the SW of the lambs was not significantly correlated with the HCY, CCY, ICL, SFT, COLOR, MARB or AOL and was negatively correlated $(\mathrm{r}=-0,08, \mathrm{P}<0,05)$ with the meat TEX (Table 7). These results were corroborated by Goes et al. (2012) in the evaluation of the performance and the characteristics of carcasses of heifers fed up to $60 \%$ of sunflower cake in their diet; they did not find a correlation between the SW and the ICL. However, Oliveira et al. (2010) found a positive correlation between the SW and the ICL.

Table 7. Pearson correlation between the performance variables of carcass and meat from lambs fed with sunflower cake.

\begin{tabular}{ccccccccc}
\hline Variables & HCY & CCY & ICL & SFT & TEX & COLOR & MARB & AOL \\
\hline SW & $-0.02 \mathrm{~ns}$ & $0.10 \mathrm{~ns}$ & $0.25 \mathrm{~ns}$ & $0.40 \mathrm{~ns}$ & $-0.08 *$ & $-0.28 \mathrm{~ns}$ & $0.49 \mathrm{~ns}$ & $0.07 \mathrm{~ns}$ \\
HCY & & $0.90^{* * *}$ & $0.07 \mathrm{~ns}$ & $0.09 \mathrm{~ns}$ & $0.28 \mathrm{~ns}$ & $-0.07 \mathrm{~ns}$ & $0.01 \mathrm{~ns}$ & $0.36 \mathrm{~ns}$ \\
CCY & & & $0.11 \mathrm{~ns}$ & $0.17 \mathrm{~ns}$ & $0.40 *$ & $0.01 \mathrm{~ns}$ & $0.05 \mathrm{~ns}$ & $0.37 *$ \\
ICL & & & & $0.46^{*}$ & $0.16 \mathrm{~ns}$ & $-0.01 \mathrm{~ns}$ & $0.05 \mathrm{~ns}$ & $0.37 \mathrm{~ns}$ \\
SFT & & & & & $0.20 \mathrm{~ns}$ & $-0.08 \mathrm{~ns}$ & $0.27 \mathrm{~ns}$ & $0.23 \mathrm{~ns}$ \\
TEX & & & & & & $0.33 \mathrm{~ns}$ & $0.07 \mathrm{~ns}$ & $0.09 \mathrm{~ns}$ \\
COR & & & & & & & $-0.27 \mathrm{~ns}$ & $-0.06 \mathrm{~ns}$ \\
MARB & & & & & & & $0.18 \mathrm{~ns}$ \\
\hline
\end{tabular}

SW- Slaughter Weight; HCY- Hot carcass yield; CCY- Cold carcass yield; ICL- Internal carcass length; SFT- Subcutaneous fat thickness; TEX- Texture; MARB- Marbling. ***- $(\mathrm{P}<0,001)$; **- $(\mathrm{P}<0,01){ }^{*}{ }_{-}(\mathrm{P}<0,05)$. 
The HCY was highly correlated $(\mathrm{r}=+0.90)$ with the CCY; therefore, with a high HCY and low losses during the cooling of the carcass, the CCY increased. The correlation these two variables permits estimations of the characteristics of the carcasses and the meat, when specific and accurate equipment is not available. The CCY was also positively correlated $(\mathrm{P}<0.05)$ with the TEX $(\mathrm{r}=$ $0.40)$ and with the AOL $(r=0.37)$.

The ICL was positively correlated $(r=0.46)$ with the SFT, an observation also reported by Oliveira et al. (2010) for Nelore heifers. For these authors, the muscularity and fat finish degree are very important in the carcass evaluation. Moreover, the loin eye area and the fat thickness, both measured at the height of the 12th rib, are internationally accepted indicators of muscularity and the amount of fat (LUCHIARI FILHO, 2000).

The color and the marbling of the meat were not significantly correlated with the other characteristics. The marbled fat is the last fat deposited on the carcass, and consequently, the expectation was that animals with a high slaughter weight would be positively correlated with marbling. However, this expectation was not realized in this research, possibly because of the feedlot period for the animals. Notably, this result affects the assessment of the commercial price of the meat because to retain heavy animals in feedlots with the expectation of increased increments of fat marbling increases the cost of production.

For the color and the texture of the meat in the carcasses, Cezar and Sousa (2007) affirmed that the primary factor was the age of the animal, which most likely explained the similarity in meat color and texture in this report ( $\mathrm{r}=0.33 \mathrm{~ns}$ ) because the lambs were all 4 months in age.

\section{Conclusions}

For lambs in intensive production systems, sunflower cake can be used as a supplement for up to $20 \%$ of the diet and should be considered, depending on the availability and cost of the product in a region.

The slaughter weights of the animals were not correlated with the yields or the characteristics of the meat.

\section{Acknowledgements}

To the "Conselho Nacional de Desenvolvimento Científico e Tecnológico (CNPq)" and the "Universidade Federal da Grande Dourados" for financial support and by scholarships awarded.

To the "EMBRAPA AGROPECUÁRIA OESTE" by the donation of sunflower cake and thanking the person who provided the machinery for the processing of sunflower grains.

\section{References}

AZEVEDO, R. A.; RUFINO, L. M. A.; SANTOS, A. C. R.; SILVA, L. P.; BONFÁ, H. C.; DUARTE, E. R.; GERASEEV, L. C. Desempenho de cordeiros alimentados com inclusão de torta de macaúba na dieta. Pesquisa Agropecuária Brasileira, Brasília, v. 47, n. 11, p. 1663-1668, 2012.

CAPPELLE, E. R.; VALADARES FILHO, S. C.; COELHO DASILVA, J. F. Estimativas do valor energético a partir das características químicas e bromatológicas dos alimentos. Revista Brasileira de Zootecnia, Viçosa, MG, v. 30, n. 1, p. 1837-1856, 2001.

CEZAR, M. F.; SOUZA, W. H. Carcaças ovinas e caprinas: obtenção, avaliação e classificação. Uberaba: Editora Agropecuária Tropical, 2007. 232 p.

DOMINGUES, A. R.; SILVA, L. D. F.; RIBEIRO, E. L. A.; CASTRO, V. S.; BARBOSA, M. A. A. F.; MORI, R. M.; VIEIRA, M. T. L.; SILVA, J. A. O. Consumo, parâmetros ruminais e concentração de ureia plasmática em novilhos alimentados com diferentes níveis de torta de girassol em substituição ao farelo de algodão. Semina: Ciências Agrárias, Londrina, v. 31, n. 4, p. 1059-1070, 2010.

FERNANDES, A. R. M.; ORRICO JUNIOR, M. A. P.; ORRICO, A. C. A.; VARGAS JUNIOR, F. M.; OLIVEIRA, A. B. M. Desempenho e características qualitativas da carcaça e da carne de cordeiros terminados 
em confinamento alimentados com dietas contendo soja grão ou gordura protegida. Revista Brasileira de Zootecnia, Viçosa, MG, v. 40, n. 8, p. 1822-1829, 2011.

GOES, R. H. T. B.; CERILO, S. L. N.; LIMA, H. L.; FERNANDES, A. R. M.; OLIVEIRA, E. R.; SOUZA, K. A.; PATUSSI, R. A.; BRABES, K. C. S.; GRESSLER, M. G. M. Torta de girassol em substituição ao farelo de soja nos suplementos de novilhas: desempenho e características de carcaça. Revista Brasileira de Saúde e Produção Animal, Salvador, v. 13, n. 2, p. 396-409, 2012.

HOUBEN, J. H.; VAN DIJK, A.; EIKELENBOOM, G.; HOVING-BOLINK, A. H. Effect of dietary vitamin E supplementation, fat level and packaging on color stability and lipid oxidation in minced meat. Meat Science, Toronto, v. 55, n. 3, p. 331-336, 2000.

KOZLOWSKY, G. V. Bioquímica dos ruminantes. 3. ed. Cidade: Santa Maria: UFSM, 2011. 214 p.

LAWRIE, R. A. Ciência da carne. 6. ed. Porto Alegre: Artmed, 2005. 384 p.

LUCHIARI FILHO, A. Pecuária da carne bovina. São Paulo: Editora: São Paulo, 2000. 134 p.

MONÇÃO, F. P.; REIS, S. T.; RIGUEIRA, J. P. S.; SALES, E. C. J.; ANTUNES, A. P. S.; OLIVEIRA, E. R.; CARVALHO, Z. G. Degradabilidade ruminal da matéria seca e da FNDda casca de banana tratada com cal virgem. Revista de Ciências Agrárias, Lisboa, v. 37, n. 1, p. 4249, 2014.
MORENO, G. M. B.; SILVA SOBRINHO, A. G.; ROSSI, R. C.; PEREZ, H. L.; LEÃO, A. G.; ZEOLA, N. M. B. L.; SOUZA JÚNIOR, S. C. Desempenho e rendimentos de carcaça de cordeiros Ile de France desmamados com diferentes idades. Revista Brasileira de Saúde e Produção Animal, Salvador, v. 11, n. 4, p. 1105-1116, 2010.

NATIONAL RESEARCH COUNCIL - NRC. Nutrient requerements of sheep. Washington: National Academy Press, 2007. 408 p.

OLIVEIRA, E. A.; SAMPAIO, A. A. M.; FERNANDES, A. R. M.; HENRIQUE, W.; ANDRADE, A. T.; ROSA, B. L.; PIVARO, T. M. Métodos de mensuração da área de olho de lombo e suas relações entre componentes da carcaça de touros jovens confinados. Revista Agrarian, Dourados, v. 3, n. 9, p. 216-223, 2010.

PALMQUIST, D. L.; MATTOS, W. R. S. Metabolismo de lipídeos. In: BERCHIELLI, T. T.; PIRES, A. V.; OLIVEIRA, S. G. (Ed.). Nutrição de ruminantes. Jaboticabal: FUNEP, 2006. p. 287-310.

PINHEIRO, R. S. B.; SOBRINHO, A. G. S.; SOUZA, H. B. A.; YAMAMOTO, S. M. Qualidade de carnes provenientes de cortes da carcaça de cordeiros e de ovinos adultos. Revista Brasileira de Zootecnia, Viçosa, MG, v. 38, n. 9, p. 1790-1796, 2009.

STATISTICAL ANALYSIS SYSTEM INSTITUTE SAS. SAS StatGuide, Release 9. 3. ed. Cary, NC: SAS Institute, 2008. 1028 p. 
